\title{
AC 2010-2222: A QUALITY MODEL OF OPENCOURSEWARE APPLIED TO ENGINEERING COURSES
}

Edmundo Tovar, Polytechnic University, Montegancedo

Nelson Piedra, Universidad Tecnica Particular de Loja

Manuel Castro, Universidad Nacional de Educacion a Distancia

Martin Llamas, Universidad de Vigo 


\title{
A Quality model of OpenCourseWare applied to Engineering courses
}

\begin{abstract}
The OpenCourseWare (OCW) project started at the Massachusetts Institute of Technology (MIT), in the year 2001, with the aim of offering pedagogical materials in an open and free of charge basis to society. The main objective of this proposal is to promote and develop higher education sharing, in a free and consistent way. The teaching resources with other educators who may re-use them for their teaching work; students; graduates and anyone in general who wants to improve its knowledge.This philosophy is being spread to the world main universities creating the OCW Consortium (OCWC), in which more than 250 Universities and Institutions collaborate. Within this context new proposals, both technical and philosophical are arising for the freely disposal of teaching resources.
\end{abstract}

Universia, the Latin-American Universities net, gather at present about 1070 universities from 11 different countries. Among its goals are: the offer of many quality services to the university community, supporting teaching and scientific research projects, encouraging the use of new technologies and promoting the business university relationship, in order to encourage a Latin-American site for knowledge

The initial conditions to include Higher Educational Institutions in this project regard three different types: educational, technical and legal matters. For the first one, it is demanded the publication of teaching materials orderly structured with at least 10 courses. Within these materials, it can be included all kind of resources: presentations, books, videos, simulations programs, etc. always with a common organization and appearances. Regarding technical demands a globally and approachable site via Internet with the right quality must be maintained. Although it has not been a requirement, most of participants have used the technology of content management based on eduCommons, an Open Source project developed by Utah State University, which include very important normalized, flexible and personalized features.

Finally, the legal aspects came from the Creative Commons License that implies to offer and publish copyright cleared materials. The use, re-use and adaptation are allowed, provided the author of material is mentioned; they are not used with commercial purposes and they are offered, at least, within the same sharing conditions.

The OCW Universia project provides member institutions with technical assistance, through Technical office of the UPM, for setting up the management and publication platform for its subjects, which constitutes the OCW site for each University.

In the current situation, with a growing number of courses publiched, quality of materials becomes as the critical priority. This paper proposes a quality model. This model has been elaborated from an initial survey among Offices of the OCW UNIVERSA Consortium. Later, this model has been applied to determine which courses of Engineering have been better evaluated.

Open Educational Resources 
The Open Educational Practices and Resources (OER) initiatives seek to use information and computing technology to help equalize access to knowledge and educational opportunities across the world $[1,2]$.

Open Educational Resources are teaching, learning, and research digital resources and tools that reside in the public domain or have been released under an intellectual property license that permits their free use, reuse or re-purposing by others.

OER initiatives are a direct reaction to knowledge privatization; they foment their global exchange with the aim of increase the human intellectual capacity. Everyday are more organizations and people that share their practices and digital learning resources through web from an Open \& Free spirit [3].

The principal idea of the movement toward Open Educational Resources is that the world's knowledge is a public good and that technology in general and the World Wide Web in particular provides an extraordinary opportunity for everyone to share, use, and reuse knowledge.

Through the OERs, teachers, students and self-taught people, have total access to courses, modules, papers, textbooks, software tools, virtual labs, audios, videos, syllabus, schedules, calendars, educational guides, lectures, tasks, evaluations, activities, games, simulations, learning objects and tools to create those components.

The access to OERs is done through the web, which actual stage shows an explosion in use and development of tools and services based on Social Software.

The next level of educational technology infrastructure will need to use semantic technologies and social tools applied to the Web (Social Semantic Web [4]).

\section{OpenCourseWare}

OpenCourseWare, or OCW, is a term applied to course materials in a virtual learning environment created by universities and shared freely with the world via the internet. The OCW movement only took off with the launch of MIT OpenCourseWare at MIT in October 2002. Since then, a number of universities have created OCW projects, some of which have been funded by the William and Flora Hewlett Foundation.

In September 2002, the MIT OpenCourseWare proof-of-concept pilot site opened to the public, offering 32 courses. In September 2003, MIT OpenCourseWare published its 500 th course, including some courses with complete streaming video lectures. By September 2004, 900 MIT courses were available online. The response from MIT faculty and students has been very positive and MIT OpenCourseWare is seen as being consistent with MIT's mission (to advance knowledge and educate students in science, technology, and other areas of scholarship that will best serve the nation and the world in the 21 st century) and is true to MIT's values of excellence, innovation, and leadership.

In 2005, MIT OpenCourseWare and other leading open educational resources projects formed the OpenCourseWare Consortium, which seeks to extend the reach and impact of open course materials, foster new open course materials and develop sustainable models for open course material publication. 
According to the website of the OCW Consortium, an OCW project:

- It iss a free and open digital publication of high quality educational materials, organized as courses.

- It is available for use and adaptation under an open license, such as a Creative Commons license.

- It does not typically provide certification or access to instructors.

\section{World Wide Movement toward Open Educational Resources}

The open trend, started with initiatives of free and open distribution of software programs and in this moment, open and free access was promoted very strongly to academic and research contents, with the purpose of support: scientific progress and innovation, the access to continuous learning and educative opportunities, and promotion of cultural diversity.

The Open Access (OA) is focused on developing digital repositories that contain books, papers, local contents with global importance and results from researches published either in indexed magazines with revision of pairs or in Open Access Publications, or Public Library of Science.

Below some of the declarations which fundament the OA:

1) Declaration of the Budapest Open Access Initiative (BOAI), the purpose of the meeting was to accelerate progress in the international effort to make research articles in all academic fields freely available on the Internet [5] (2002)

2) Bethsda Statement on Open Access Publishing (2003).

3) Berlin Declaration on Open Access to Knowledge in the Sciences and Humanities (2003).

4) Organization for Economic Cooperation and Development, OECD declaration on access to research data from Public Funding (2004).

5) The Cape Town Open Education Declaration arises from a small but lively meeting convened in Cape Town, South Africa, in September 2007.

The aim of these meetings was to accelerate efforts to promote open resources, technology and teaching practices in education.

\section{OER Initiatives}

Open education and open educational resources (OER) continue to explode.

OpenCourseWare (OCW) from MIT is well known but just a small percent of all the course material now available free. MIT OCW can be considered a large-scale, Webbased publication of MIT course materials and not as an interactive experience with the MIT faculty.

The importance of OER has been fortified by international and national organizations initiatives, implicated in create and share digital resources freely and openly. Some of them initiatives are: Massachusetts Institute of Technology, MIT, in 2001 with its project OpenCourseWare and its OCW Consortium [6]. 
On OCW projects, educators were encouraged to utilise the materials for curriculum development and self-learners may use the materials for self-study or supplementary use.

Others initiatives are, projects from Centre for Educational Research and Innovation (OECD) [7], UNESCO Initiative through International Institute for Educational Planning [8]; the Open University's Open Learn Project, the website gives free access to course materials from The Open University; Rice Connexions Project a place to view and share educational material made of small knowledge chunks called modules that can be organized as courses, books, reports, etc.; Utah State OpenCourseWare; Universia MIT OCW - Spain; OCW Consortium of Chinese institutions CORE, IEEESPS be working with the open-access repository project Connexions on a major initiative to develop a critical mass of signal processing educational modules and courses that will be available for free access by anyone, anywhere, at any time.

\section{OCW Initiatives in the World}

Africa Virtual University
China Open Resources Exchange (CORE)
Connexions (Rice University)
Creative Commons
Etudes NG
Hewlett Foundation, William and Flora
(Open Educational Resources)
History Matters
Internet Archive
Sakai
Berkeley Digital Library
Japan Open Courseware Consortium
Mellon, Andrew Foundation
MIT OpenCourseWare
Open Courseware Consortium
Open University (UK)
Science Commons
Stanford Encyclopedia of Philosophy
Paris Tech
Universia (Portuguese)
Universia (Spanish)
Wikipedia
World Bank Development Gateway

\author{
http://www.avu.org/default.asp \\ http://www.core.org.cn/en/index.htm \\ http://cnx.org \\ http://creativecommons.org \\ http://etudes-ng.fhda.edu/portal \\ http://www.hewlett.org/Programs/Education \\ IOER \\ http://www.historymatters.gmu.edu \\ http://www.archive.org/details/index \\ http://sakaiproject.org/ \\ http://sunsite.berkeley.edu/ \\ http://www.jocw.jp \\ http://www.mellon.org \\ http://ocw.mit.edu/index.html \\ http://ocwconsortium.org \\ http://oci.open.ac.uk \\ http://sciencecommons.org/ \\ http://plato.stanford.edu \\ http://graduateschool.paristech.org/ \\ http://universiabrazil.net/mit/index.jsp \\ http://mit.ocw.universia.net/ \\ http://en.wikipedia.org/wiki/Main_Page \\ http://topics.developmentgateway.org/opene \\ ducation
}

\section{Quality Model in OCW contents}

An OCW Initiative is not distance learning, or a degree-granting initiative, there is no registration process required for users to view course materials. An OCW Initiative is a publication of the course materials that supports the dynamic classroom interactions of universty education. OCW is completely free and is open for users anywhere around 
the world. There is no certification or degree offered upon use or completion of any of the materials. Here, educators are encouraged to use materials for curriculum development and self-learners are encouraged to draw upon the materials for self-study or supplementary use. Therefore, course materials which are contained on one OCW website can be used, copied, distributed, translated and modified, but only for noncommercial or educational purposes. This OCW materials will be totally available to others.

Nowadays, the OCW systems and OER face two major challenges: to expand the reach of education and to improve their quality. Traditional solutions for education are not enough, especially within the context the knowledge-intensive of today's societies.

The goal of the Open Educational Resources (OER) movement is to equalize access to the worldwide knowledge through a high quality content available openly and freely online.

Here, a set of categories to quality assurance on OCW/OER contents can be described as follow:

- OCW/OER Developers, Distribution Models and Licensing Models

- Breadth and depth of the content and OCW/OER audience

- Content and user interface

- Assessments and Support Materials

- Technology requirements and Interoperability

- OCW/OER Universal Design and Accessibility

- Open Repositories Use

Next, in the following tables, the criteria are defined by categories. 
Table I. OCW/OER Developers, Distribution Models and Licensing Models

\begin{tabular}{|c|c|}
\hline Evaluation Area & Context, Aims and Evaluation Goal \\
\hline $\begin{array}{l}\text { OCW/OER Developers, } \\
\text { organizational status }\end{array}$ & $\begin{array}{l}\text { The mission of OpenCourseWare and OER developers is } \\
\text { to foster a global community that shares knowledge and } \\
\text { open-source tools focused on providing educational } \\
\text { opportunity. } \\
\text { Developer organizational status refers to the commercial } \\
\text { or non- profit status of the OCW developer and whether } \\
\text { the organization must be self-sustaining based on the } \\
\text { distribution of online courses, or whether the courses are } \\
\text { developed and distributed as part of its mission and not } \\
\text { for financial gain. } \\
\text { OCW creators aim to develop high quality educational } \\
\text { materials and cost-effective tools that will facilitate the } \\
\text { delivery of content to the global community of learners. } \\
\text { Success will be measured by the delivery and value of } \\
\text { content and functional tools to global users } \\
\text { OCW is a free and open educational resource for faculty, } \\
\text { students, and self-learners throughout the world. OCW } \\
\text { projects do not grant credits or degrees, and does not } \\
\text { provide access to faculty. }\end{array}$ \\
\hline $\begin{array}{l}\text { Licensing models to use, } \\
\text { share, re-use and re-mix } \\
\text { legally }\end{array}$ & $\begin{array}{l}\text { Licensing models refers to how open courses and OER } \\
\text { owned by an institution are made available to other } \\
\text { institutions, organizations and people independent. } \\
\text { Licensing models define how and when a licensing } \\
\text { institution must pay for a course and any other } \\
\text { stipulations for access and distribution. } \\
\text { Creative Commons is a non-profit organization dedicated } \\
\text { to making it easy and legal for people to build upon the } \\
\text { work of others, consistent with the rules of copyright. } \\
\text { Creative Commons provides easy and effective tools for } \\
\text { OER and OCW creators to share their creative work when } \\
\text { they want to. The resulting ability to share and collaborate } \\
\text { enables new forms of creativity (cultural, educational, and } \\
\text { scientific content) in "the commons" - the body of work } \\
\text { that is available to the public for free and legal sharing, } \\
\text { use, repurposing, and remixing and enriches us all. }\end{array}$ \\
\hline \begin{tabular}{ll} 
Distribution & \multicolumn{2}{c}{ Framework } \\
(distribution & model and \\
content & management \\
system) &
\end{tabular} & $\begin{array}{l}\text { Distribution of the open course refers to the model used to } \\
\text { make the course available to its intended course } \\
\text { participants. Courses can be distributed for use on virtual } \\
\text { campus (moodle, WebCT) or through a single institution, } \\
\text { through open public websites (EduCommons, Joomla, } \\
\text { Wordpress, Wiki), and through broker web sites. }\end{array}$ \\
\hline
\end{tabular}

Table II. Breadth and depth of the content and OCW/OER audience 


\begin{tabular}{|c|c|}
\hline Evaluation Area & Context, Aims and Evaluation Goal \\
\hline Grade Level of Audience & $\begin{array}{l}\text { Grade level or audience refers to the specific group of } \\
\text { learners for whom the OCW/OER has been designed. } \\
\text { A key OER/OCW audience is educators, and for them, we } \\
\text { are hoping that by providing the syllabus, reading lists } \\
\text { and lecture notes, we are offering a chance for them to } \\
\text { jumpstart their own pedagogy and improve the way they } \\
\text { teach their chosen discipline. }\end{array}$ \\
\hline Writing style and accuracy & $\begin{array}{l}\text { Writing style refers to the level of diction and engagement } \\
\text { and the choice of words used to present the course } \\
\text { concepts. Accuracy refers to correct punctuation, } \\
\text { grammar and sentence structure used in a written piece, as } \\
\text { well as the absence of typographical errors. }\end{array}$ \\
\hline Breadth of coverage & $\begin{array}{l}\text { Focus on depth of understanding rather than breadth of } \\
\text { content. Depth versus breadth: Still too broad to "study } \\
\text { topics in sufficient breadth to develop deep conceptual } \\
\text { understanding." }\end{array}$ \\
\hline $\begin{array}{lll}\text { Course } & \text { orientation } & \text { and } \\
\text { syllabus } & & \end{array}$ & $\begin{array}{l}\text { This category refers to the course information, student } \\
\text { training and support materials, syllabus and other } \\
\text { resources available to the user as they enter the course. } \\
\text { The OCW course orientation, along with the course } \\
\text { syllabus, plays a very important role in an OCW } \\
\text { course because both the orientation and the syllabus } \\
\text { provide a student with critical course and support } \\
\text { reference information. To OCW course, an online } \\
\text { orientation is required. There are several things to } \\
\text { consider when designing the orientation. For example, } \\
\text { are you going to post the orientation on an external } \\
\text { web site or have it contained entirely within OCW } \\
\text { site? What format will it be in HTML? PDF? Flash } \\
\text { animation? Steaming video (i.e. YouTube)? Will it be } \\
\text { text only or will it also have graphics, audio, video and } \\
\text { other media? Is most of the orientation information } \\
\text { also covered in the course syllabus? Is also need to } \\
\text { consider when the orientation will be delivered, what } \\
\text { contingencies have been arranged to accommodate } \\
\text { open content users }\end{array}$ \\
\hline $\begin{array}{lr}\text { Writing } & \text { Clear } \quad \text { and } \\
\text { Measurable } & \text { Learning } \\
\text { Objectives } & \end{array}$ & $\begin{array}{l}\text { Learning objectives are central to the accreditation } \\
\text { process. Learning objectives are the goals that the learner } \\
\text { should achieve in the course. The articulation of learning } \\
\text { objectives, sometimes referred to as instructional } \\
\text { objectives or competencies, } \\
\text { is central to the educational process. Instructional } \\
\text { objectives are statements that describe learning that a } \\
\text { participant should demonstrate at the end of instruction. } \\
\text { Learning objectives can be laid out for any level of } \\
\text { instruction, such as course learning objectives, unit } \\
\text { objectives, and topic objectives. }\end{array}$ \\
\hline Instructional philosophy & It is recommended start the course design process with \\
\hline
\end{tabular}




\begin{tabular}{|c|c|}
\hline & $\begin{array}{l}\text { the learning objectives for each section or topic area. } \\
\text { Work backwards from the learning objectives to } \\
\text { determine the most optimal way, in an OCW } \\
\text { environment, to accomplish the course's learning } \\
\text { objectives. } \\
\text { Some of OCW Instructional Design considerations } \\
\text { are: } \\
\text { - How will the course's activities, documents, exercises, } \\
\text { assignments and interactive elements support the } \\
\text { learning objectives? } \\
\text { - How will technology be used and how will that } \\
\text { technology support the learning objectives? } \\
\text { - How will understanding of the course's learning } \\
\text { objectives be auto-evaluated? } \\
\text { - What media will be used and how will that media } \\
\text { support the course's learning objectives? }\end{array}$ \\
\hline Copyright Considerations & $\begin{array}{l}\text { Since a OCW course often uses a wide variety of media, } \\
\text { graphics, web sites and other online materials, it is } \\
\text { important that OCW developers familiarize themselves } \\
\text { with Copyright and Fair Use Administrative Rule (e.g. } \\
\text { creative commons licences). } \\
\text { Before developing and designing OCW course materials, } \\
\text { it is recommended that instructors review Copyright } \\
\text { Ownership Administrative Rule. This administrative rule } \\
\text { defines intellectual property developed by OCW } \\
\text { developers, outlines disclosure procedures, describes } \\
\text { royalties, as well as the production of intellectual } \\
\text { property. }\end{array}$ \\
\hline
\end{tabular}

Table III. User Interface

\begin{tabular}{|l|l|}
\hline Evaluation Area & Context, Aims and Evaluation Goal \\
\hline OCW Course Navigation & $\begin{array}{l}\text { The navigation scheme for OCW course acts as its road } \\
\text { map, with clearly marked destinations, roads that } \\
\text { intertwine, and even suggested routes. Visitors to your } \\
\text { neck of the Net will want to know three things: where } \\
\text { they are, where they can go, and how they can get back to } \\
\text { where they came from. }\end{array}$ \\
\hline $\begin{array}{l}\text { How to design good user } \\
\text { interfaces }\end{array}$ & $\begin{array}{l}\text { Design: How to design good user interfaces, starting with } \\
\text { human capabilities (including the human information } \\
\text { processor model, perception, motor skills, color, attention, } \\
\text { and errors) and using those capabilities to drive design } \\
\text { techniques: task analysis, user-centered design, iterative } \\
\text { design, usability guidelines, interaction styles, and graphic } \\
\text { design principles. }\end{array}$ \\
\hline
\end{tabular}


Techniques for evaluating and measuring interface usability
Techniques for evaluating and measuring interface usability, including heuristic evaluation, predictive evaluation, and auto-testing.

Table IV. Assessments and Support Materials

\begin{tabular}{|c|c|}
\hline Evaluation Area & Context, Aims and Evaluation Goal \\
\hline $\begin{array}{l}\text { Assessment, pedagogical } \\
\text { consideration }\end{array}$ & $\begin{array}{l}\text { Methods and procedures for formative OCW courses } \\
\text { evaluation should be carefully planned in the OCW } \\
\text { course design process. } \\
\text { The syllabus of OCW course must be seen in relation to } \\
\text { the basic knowledge acquired by participant about the } \\
\text { teaching-learning process and the use of educational } \\
\text { resources. The learning objectives have been stated } \\
\text { clearly and with measurable outcomes. } \\
\text { The course content and assessment methods are designed } \\
\text { to measure the stated learning objectives. Learning } \\
\text { activities and assessments are clearly connected with } \\
\text { learning objectives. The course content is sequenced and } \\
\text { structured to enable learners to achieve the stated goals. }\end{array}$ \\
\hline $\begin{array}{l}\text { Pre-requeriments and } \\
\text { Academic Expectations }\end{array}$ & $\begin{array}{l}\text { OCW course clearly states academic expectations and } \\
\text { support. Explain what it takes to be a successful student } \\
\text { such as time management, self- sufficiency, and technical } \\
\text { abilities. OCW provide information about academic } \\
\text { assistance. }\end{array}$ \\
\hline $\begin{array}{l}\text { Course Requirements and } \\
\text { Participant Support }\end{array}$ & $\begin{array}{l}\text { OCW Course plan clearly states technical requirements } \\
\text { and support: provide hardware and software requirements } \\
\text { and links to necessary viewers and plug-ins, communicate } \\
\text { necessary minimum technical abilities and competencies } \\
\text { to students, and include information about technical } \\
\text { assistance. }\end{array}$ \\
\hline $\begin{array}{l}\text { Additional for } \\
\text { resources the } \\
\text { instructor/student }\end{array}$ & $\begin{array}{l}\text { Support materials for the instructor may include prepared } \\
\text { teacher notes, optional simulated lab materials, extra } \\
\text { credit assignments not included in the body of the course } \\
\text { content, etc. } \\
\text { Support materials for the student may include optional } \\
\text { tutorials, third party problem sets, lab simulations, test } \\
\text { preparation materials, graphing or math equation } \\
\text { open/free software, etc. }\end{array}$ \\
\hline
\end{tabular}

Table V. Technology requirements and Interoperability

\begin{tabular}{|l|l|}
\hline Evaluation Area & Context, Aims and Evaluation Goal \\
\hline Interoperability standards & $\begin{array}{l}\text { Promotion of interoperability standards that aim to } \\
\text { facilitate the dissemination of content, by enhancing } \\
\text { access to OER and OCW repositories. } \\
\text { Interoperability standards refer to achievement }\end{array}$ \\
\hline
\end{tabular}




\begin{tabular}{|c|c|}
\hline & $\begin{array}{l}\text { interoperability of educational content on a large scale, } \\
\text { using standards on two ways: (a) Interoperable Content: } \\
\text { OCW content is now packaged for interoperation with a } \\
\text { variety of teaching and learning systems, according to } \\
\text { standards. (b) Web Services: OCW content can now be } \\
\text { transported across the network amongst those systems; by } \\
\text { means of a service, oriented architecture developed using } \\
\text { SOAP standards. }\end{array}$ \\
\hline Course Format & $\begin{array}{l}\text { Course format refers to the delivery method for the course } \\
\text { content and how the students access it. Course formats } \\
\text { can also include hybrid courses that utilize the classroom } \\
\text { and online delivery. } \\
\text { An OCW course delivery method that is provided in an } \\
\text { asynchronous mode through Internet technologies. }\end{array}$ \\
\hline Compatibility for remixing & $\begin{array}{l}\text { This category refers to technology and licenses (e.g. } \\
\text { Creative Commons, GNU Free Documentation License) } \\
\text { compatibility for the purposes of remixing OER/OCW } \\
\text { content. } \\
\text { Remix refers to the ability to combine different resources } \\
\text { together to create new derivative works. Creators of } \\
\text { OER/OCW can often combine learning objects from a } \\
\text { variety of sources together, or add their own creativity to } \\
\text { existing works to create a new educational resource that } \\
\text { they in turn re-license openly. } \\
\text { However, the legal terms of one license may not be } \\
\text { compatible with the legal terms of another license. Some } \\
\text { licenses are incompatible with others. CC licenses may } \\
\text { apply to your remixes, depending on the license terms of } \\
\text { the underlying materials you choose to use. }\end{array}$ \\
\hline $\begin{array}{l}\text { Use of Protocols for } \\
\text { syndcation: XML and RSS } \\
\text { for }\end{array}$ & $\begin{array}{l}\text { XML and RSS are standardized protocols, which permit } \\
\text { end-users to make use of a site's data in another context } \\
\text { (such as another website, a browser plugin, or a separate } \\
\text { desktop application). } \\
\text { Protocols which permit syndication include RSS (Really } \\
\text { Simple Syndication - also known as "web syndication"), } \\
\text { RDF (as in RSS 1.1), and Atom, all of them XML-based } \\
\text { formats. Observers have started to refer to these } \\
\text { technologies as "Web feed" as the usability of Web } 2.0 \\
\text { evolves and the more user-friendly Feeds icon supplants } \\
\text { the RSS icon. } \\
\text { Specialized protocols such as FOAF and XFN (both for } \\
\text { social networking) extend the functionality of sites or } \\
\text { permit end-users to interact without centralized websites. }\end{array}$ \\
\hline $\begin{array}{lll}\text { OCW/OER } & \text { websites } & \text { and } \\
\text { SLATES } & \text { features } & \text { and } \\
\text { techniques } & & \end{array}$ & $\begin{array}{l}\text { It is very importan that OCW websites typically include } \\
\text { some of the following features and techniques insipired in } \\
\text { Social Web. The category makes many sensible } \\
\text { observations around web } 2.0 \text { features. Andrew McAfee } \\
\text { used the acronym SLATES to refer to them: } \\
\text { Search, finding OCW/OER quality content through }\end{array}$ \\
\hline
\end{tabular}




\begin{tabular}{|l|l|}
\hline Leyword search. & Links, connects OCW/OER sites together into a \\
meaningful information ecosystem using the model of the \\
Web, and provides low-barrier social tools. \\
Authoring, the ability to create and update content leads \\
to the collaborative work of many rather than just a few \\
web authors. In wikis, users may extend, undo and redo \\
each other's work. In blogs, posts and the comments of \\
individuals build up over time. \\
Tags, categorization of content by users adding one-word \\
descriptions to facilitate searching, without dependence \\
on pre-made categories. This is referred to as \\
"folksonomy". \\
Extensions, software that makes the Web an application \\
platform as well as a document server. \\
Signals, the use of syndication technology such as RSS to \\
notify users of content changes. \\
The long tail of OCW/OER repositories
\end{tabular}

Table VI. OCW/OER Universal Design and Accesibility

\begin{tabular}{|c|c|}
\hline Evaluation Area & Context, Aims and Evaluation Goal \\
\hline \begin{tabular}{lll} 
Universal & \multicolumn{2}{c}{ Design for } \\
reducing and eliminating \\
barriers to OCW/OER \\
access.
\end{tabular} & $\begin{array}{l}\text { This category is related to reducing / eliminating barriers } \\
\text { to OCW/OER access. } \\
\text { Accessibility is a general term used to describe the degree } \\
\text { to which an OCW course or Open Educational Resource } \\
\text { is accessible by as many people as possible. Accessibility } \\
\text { can be viewed as the "ability to access" and possible } \\
\text { benefit of some system or entity. Accessibility is often } \\
\text { used to focus on people with disabilities and their right of } \\
\text { access to entities, often through use of assistive } \\
\text { technology. } \\
\text { Accessibility is strongly related to universal design when } \\
\text { the approach involves "direct access". This is about } \\
\text { making things accessible to all people (whether they have } \\
\text { a disability or not). }\end{array}$ \\
\hline $\begin{array}{l}\text { W3C accessibility } \\
\text { OCW/OER sites }\end{array}$ & $\begin{array}{l}\text { It is essential that the Web be accessible in order to } \\
\text { provide equal access and equal opportunity to people } \\
\text { Accessibility can be thought of as "providing access } \\
\text { regardless of the situation or circumstances." In the } \\
\text { context of the World Wide Web, accessibility is a } \\
\text { measure of how easy it is to access, read, and understand } \\
\text { the content of a Website. Accessible design is a prime } \\
\text { way to prepare for next-generation user interfaces. }\end{array}$ \\
\hline
\end{tabular}

Table VII. Use de Open repositories

\begin{tabular}{|l|l|}
\hline Evaluation Area & Context, Aims and Evaluation Goal \\
\hline Use of Open Content & Open content repositories intends to initiate a dynamical \\
\hline
\end{tabular}




\begin{tabular}{|l|l|}
\hline Repositories & $\begin{array}{l}\text { process: based on an initial resource, content should be } \\
\text { used, enriched, improved, and then provided to the } \\
\text { community again This dynamical process can lead to an } \\
\text { exponential increase in the number of resources (and re- } \\
\text { users). } \\
\text { The use of open content repositories means that an } \\
\text { adaptation process is necessary when re-using or re- } \\
\text { contextualizing OCW/OER. Adaptation means that for } \\
\text { example OCW, OER or knowledge pieces are modified } \\
\text { for usage in a new context. This adaptation process can } \\
\text { differ in the degree of adaptation needs: from minor } \\
\text { adaptation (e.g., changing media formats) to a full re- } \\
\text { authoring (e.g., translation, adaptation to a different } \\
\text { culture) }\end{array}$ \\
\hline
\end{tabular}

\section{Quality model apropriate for the OCW UNIVERSIA Consortium}

This quality model has been used as a way to know the preferences of the OCW Offices from Spanish universities. A survey was designated including the criteria of this model. In the survey, 16 universities have participated. They coincide in some reasons of why the quality control is important in their offices. Outstand the importance of checking the quality of the materials published, procedures to recognice the participation of authors or the delivery of awards to best materials and others.

The Universities that participated have identified general information about own budget for OCW projects and the support of the university different resources.

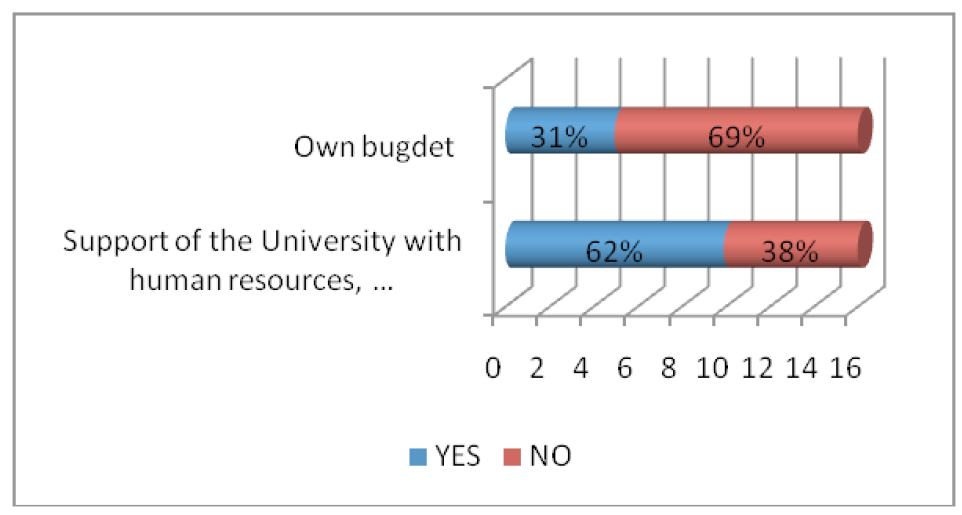

Figure 1. General information OCW -University and External Support

In order to emphasize that few Universities manage their own budgets for the generation of their OCW projects, this is being one management aspect that be has improved. Moreover, the Universities are betting on OCW with some human, material and technological resources. 
It is worth saying that professors who participate in OCW projects have services and facilities for resource development. Besides, the professors will receive additional benefits both tangible and intangible.

Technical support in the publication

Legal advice for the integrity of intellectual property

Accompaniment in the adaptation of materials, migration of virtual platforms

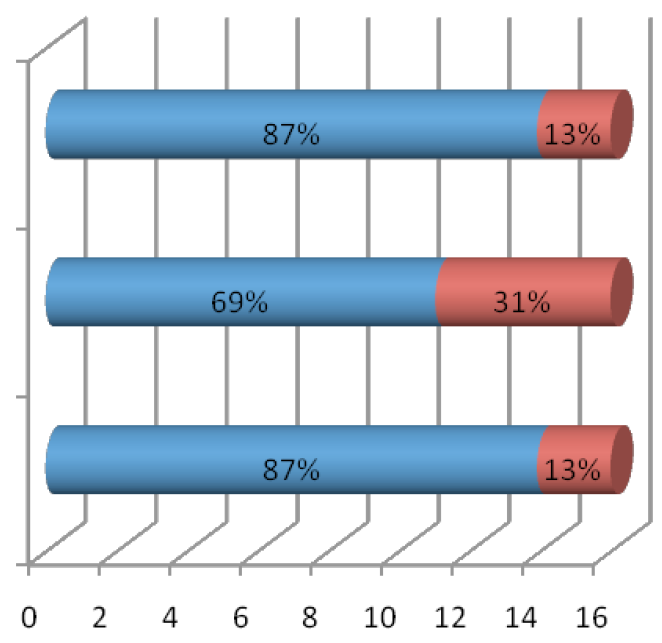

$\square$ YES $\square$ NO

Figure 2. Services - Facilities for participating teachers

In this regard, it appears that there is complete support in terms of accompanying services and facilities for professors working with the initiative. They also have the support of scholarship students in editing materials, ICT consultancy, web pages development, training and updating format changes to files, both legal and pedagogical. It can also highlight opportunities and achieve economic incentives, and other intrinsic benefits such as recognition and prestige of the author.

The process of publishing courses include a selection of the best courses, from the participating universities. The universities must have considered relevant aspects such as the target audience target and a variety knowledge areas.

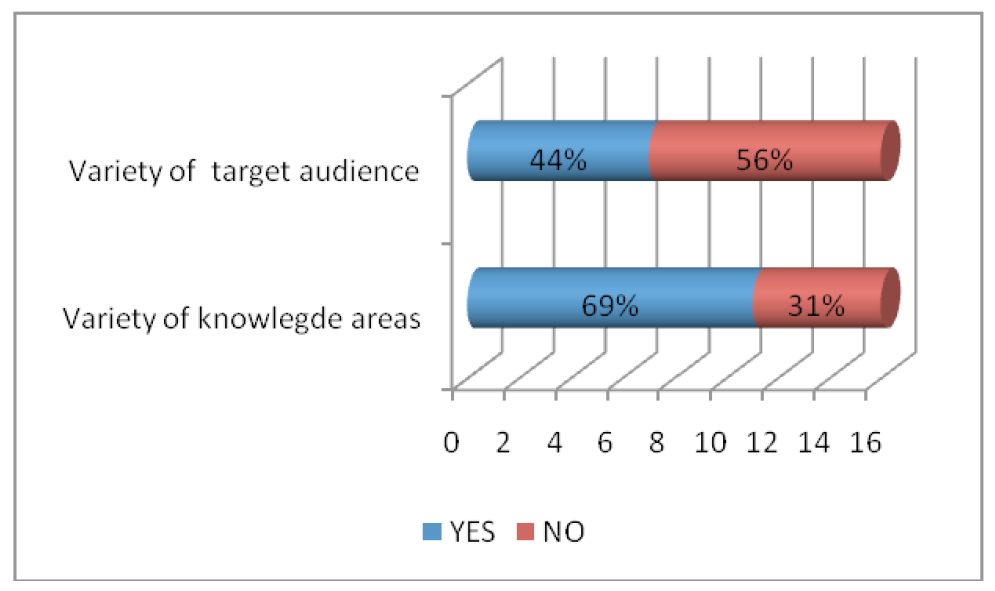


Figure 3. Criteria for selection of courses

The survey has identified a variety of knowledge areas involved in the publication process, but little diversity of course target. It is necessary to analyze the impact of the latter and encourage it as a key factor

The previous model has been revised and adapted to the needs of UNIVERSIA. Organizing the quality criteria in several categories: design of the course, material contents, learning progress evaluation, technological richness, accesibility, web presentation and didactical richness. The results of opinions of the universities inquired have showed in the following figures.

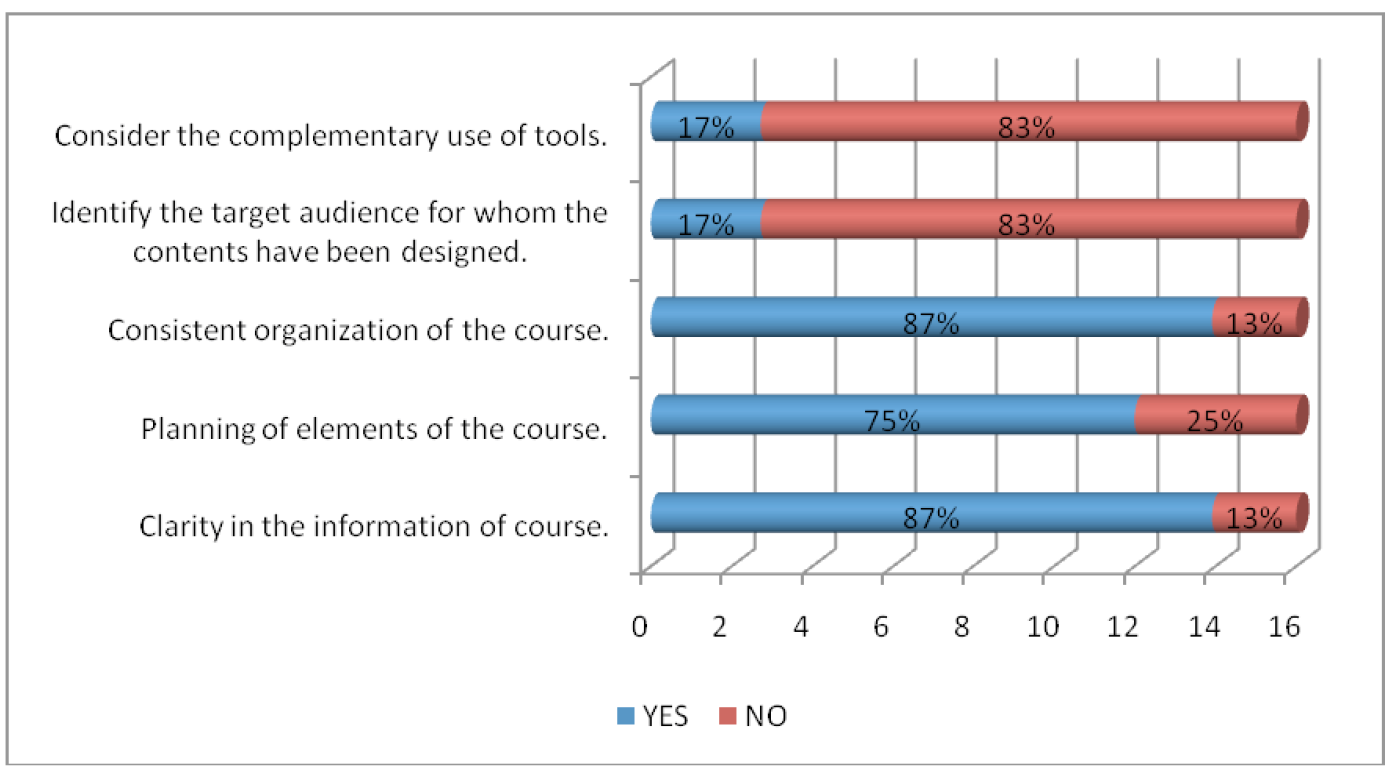

Figure 4. Results for Design of the Course criteria

Clarity in the general information of the course, a consistent organization of contents and planning of elements of the course are the most important criteria assessed by the OCW Offices. The universities in the study have not given priority for consideration of use of complementary tools also are not allocating resources to identify the target audience for their courses, these being the following points that should be strengthened in the area of course design. 


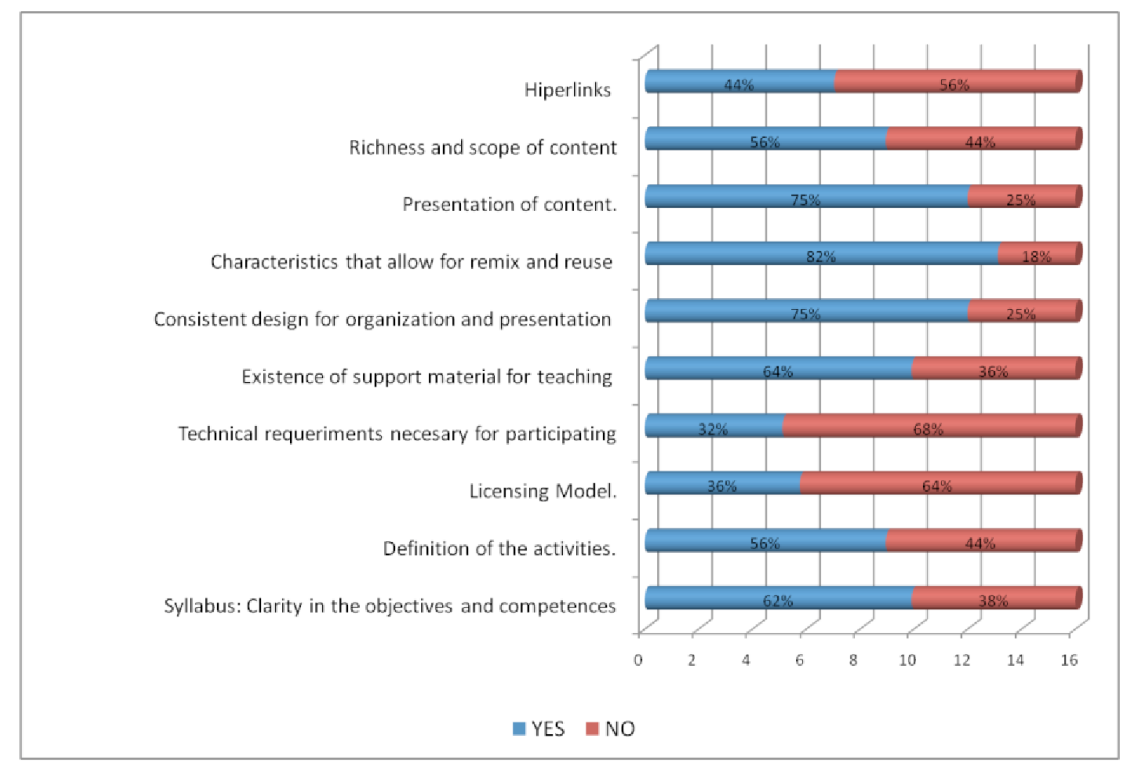

Figure 5. Results for Contents criteria

The results show strengths as content presentation, resources with features like remix and reuse, consistent design for good a organization and presentation of the course. Besides, the presence of learning support resources and study materials, as well as the course syllabus that guides students in the process of acquiring the setting skills.

There are also some aspects that until this moment are not have relevant, but it this survey is an opportunity to improve aspects like such as richness and scope of content, to incorporate hyperlinks, standardize technical requirements for participating, working with an open licensing model, and set the activities to be developed in the course.

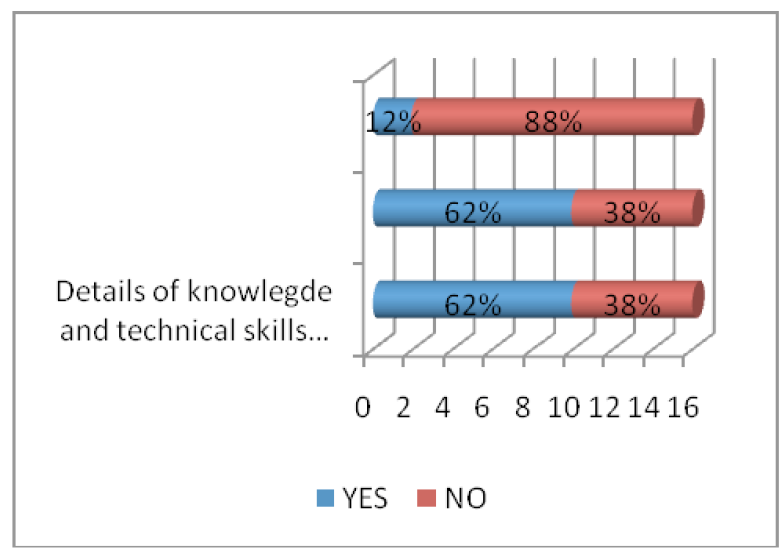

Figure 6. Results for Progress Evaluation criteria

According to participants' opinion in this survey, the require courses firstly a description of the skills and previous knowledge and procedures to evaluate the learning process. Nowadays, there is not assessment of the effectiveness resources although it is begining to be consider an important element. 


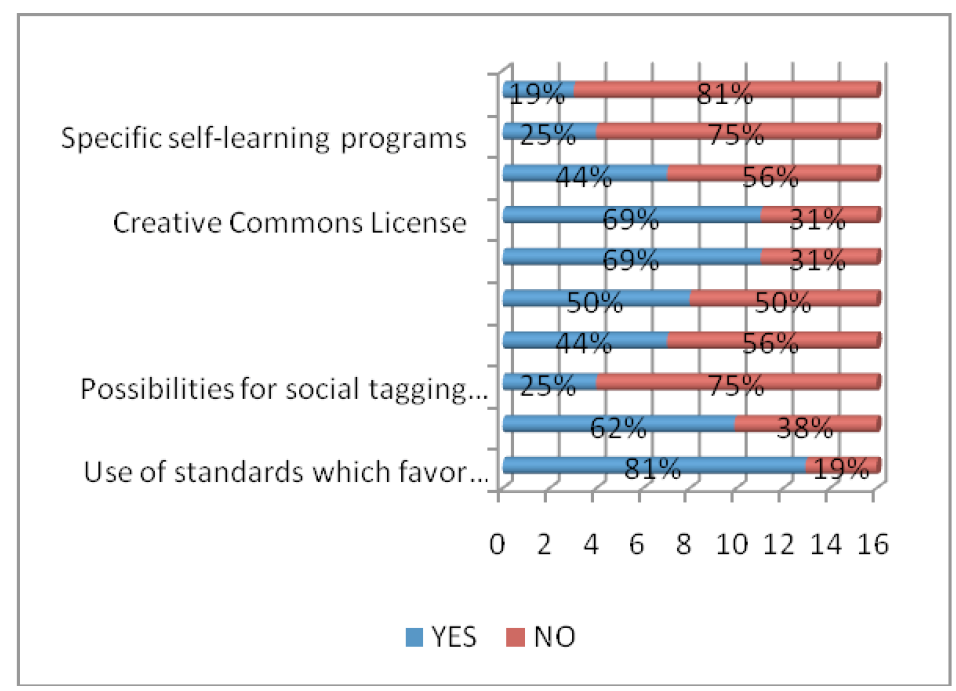

Figure 7. Results for technological criteria

Use of standards and Creative Commons licences are the best assessed.

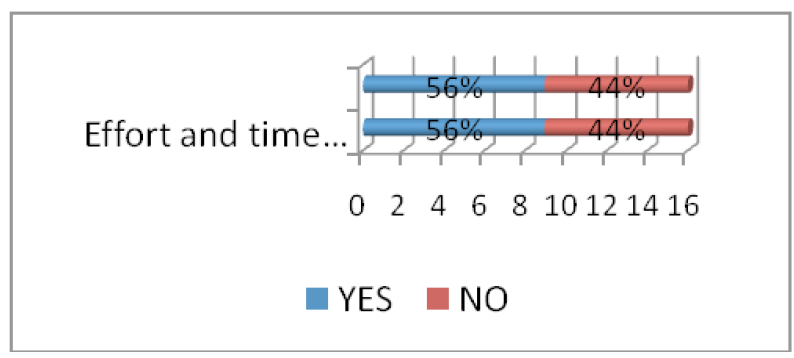

Figure 8. Results for accesibility criteria

There is no difference in importance betwwen the conformity with W3C standards and other criteria as time and effort applied to find specific information of the course.

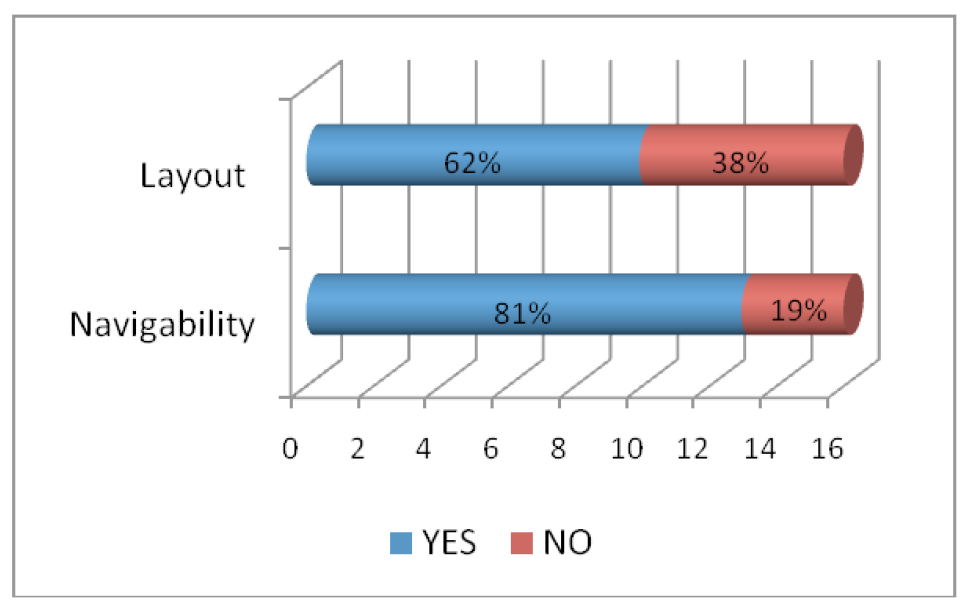

Figure 9. Results for Web presentation criteria 
Navegability is priority versus others as visual attraction or layout.

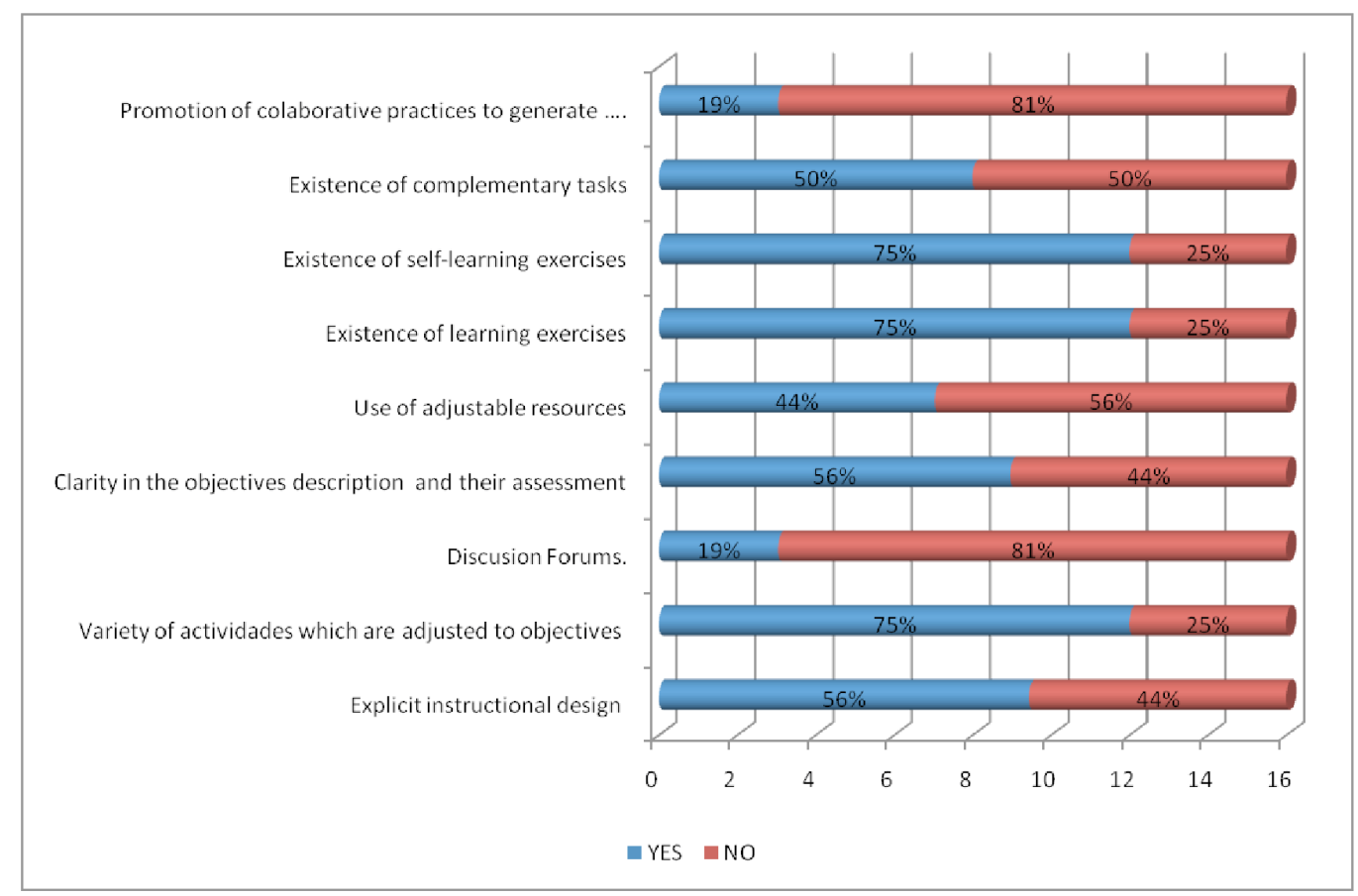

Figure 10. Results for Didactic resources criteria

The best resources considered have been self-evaluation and evaluation exercises, and the design of learning activities developed by the authors. Aspects should to be considered to enrich the OCW courses are as follows: promotion of collaborative practices to generate more knowledge; incorporate discussion forums; improve the objectives description and assessments; design appropriate instructional specifications and finally propose additional tasks for learning.

\section{Conclusions}

Although OER offers significant opportunities for innovation in education, there is a need for long-term funding to realize that potential. The imbalance between developing and developed countries in the use of technology for education means that there is a need for economic models that promote equality in access, production and use of open content, irrespective of geography or social and ethnic background. Quality touches everything and is central to most research areas - OCW/OER creation, commons-based peer production [9], technology investigations, dissemination, learning patterns, etc. It was noted that quality OCW/OER is the result of quality OER development processes, and that quality OER practice is a fertile area for research.

This paper has proposed a specific quality model for OCW materials that has been applied in the environment of the OCW UNIVERSIA Consortia. Participants in the study expressed a need for guidelines that set out quality and interoperability criteria and observed that quality standards for one situation might not be applicable to another. 
The first application of this study has been the identification of the main criteria to be considered in the next call of awards in 2010 of OCW courses funded by UNIVERSIA and the Spanish Education Ministry.

\section{Acknowledgments}

Authors wish give thanks to the OCW UPM Office staff, and the OCW UNIVERSIA Consortium by their support to this study.

\section{References}

1. OEDB. (2007, April). 80 open education resource (OER) tools for publishing and development initiatives (Tech. Rep.). OEDB - Online Education Database.

2. OLCOS. (2007). Open Educational Practices and Resources. OLCOS Roadmap 2012 (A. Guntram Geser Salzburg Research / EduMedia Group, Ed.) (No. ISBN 3-902448-08-3). Open eLearning Content Observatory Services.

3. T. O'Reilly (2005). What is web 2.0? Design patterns and business models for the next generation of software. (Tech. Rep.). O’Reilly Network.

4. A. Ankolekar, M. Krötzsch, T. Tran, D. Vrandecic: Die zwei Kulturen. Social Semantic Web 2009: 99-123

5. BOAI. (2002). Declaration of the Budapest Open Access Initiative (Tech. Rep.). http://www.soros.org/openaccess/

6. MIT-OCW. (2001). MIT OpenCourseWare. Massachusetts Institute of Technology. Online http://ocw.mit.edu/.

7. OECD, "Giving Knowledge for Free. The Emergence of Open Educational Resources". Centre for Educational Research and Innovation (CERI), 2007. (Book style)

8. IIEP (2005-2008). International institute for educational planning community of interest on open educational resources, online http://oerwiki.iiep-unesco.org. (Tech. Rep.). UNESCO.

9. Benkler, Y. 2002. Coase's penguin, or, Linux and the nature of the firm. The Yale Law Journal, Vol. 112, No. 3, pp. 369-446. 